\title{
Zainteresiranost učenika petih razreda za teme vezane uz istraživanje tla
}

Marina Balažinec

III. osnovna škola Varaždin, Trg Ivana Perkovca 35 marina.barisic13@gmail.com

\begin{abstract}
SAŽETAK
Kurikulum predmeta Priroda donesen 2019. godine naglasak stavlja na razumijevanje osnovnih prirodoslovnih koncepata i upoznavanje svijeta u kojem je učenik sposoban donositi odgovorne odluke i održivo živjeti. Sadržajno se znatno promijenio te prema njemu učenici istražuju svijet koji ih okružuje provodeći mjerenja i opažanja. Jedna od cjelina koja se obrađuje je i istraživanje tla. Kako je tlo do sada bilo vrlo malo zastupljeno u redovnoj nastavi petog razreda osnovne škole cilj ovog rada bio je ispitati zainteresiranost 37 učenika petih razreda III. osnovne škole Varaždin za istraživanje sadržaje vezanih uz cjelinu Tlo. Učenici su tijekom prvog polugodišta (od 9. do 12. mjeseca) ispunili pet anketnih upitnika putem online obrasca Google forms na satu Prirode pomoću mobilnih i tablet uređaja. Rezultati su pokazali visoku motivaciju za učenje Prirode kao i za istraživanje tla, važan im je uspjeh i žele postići što bolji rezultat iz Prirode. Pokazali su također da o tlu imaju određeno predznanje, ali nije ima jasno kako nastaje i važnost tla spominju samo kao podlogu za rast i gradnju. Izrazili su pozitivan stav prema grupnom kolaboracijskom radu, a željeli bi više vremena provoditi vani. Istraživanje bi trebalo provesti na većem uzorku ispitanika $i$ istražiti povezanost između kolaboracijskog grupnog rada, ozračja i korištenih strategija prilikom učenja, te motivacije za učenje Prirode, zainteresiranosti za istraživanje tla i strategija korištenih tijekom učenja.
\end{abstract}

Ključne riječi: istraživanje tla; anketa; kolaborativno učenje; motivacija; razredno ozračje

\section{UVOD}

Obrazovanje je jedno od ključnih faktora razvoja društva. Ono pomaže pojedincu razumjeti sebe i svoju okolinu te poboljšati kvalitetu svojeg života i života zajednice u kojoj živi (Barać, 2019). Zbog globalizacije ekonomije, komunikacija, informacija i tehnologija promijenio se status i društvena uloga obrazovanja (Baranović 2006a). Obrazovanje i vještine počeli su dobivati na značaju kao ključne odrednice produktivnosti pojedinca i države (Barać, 2019) te postaju sastavni dio nacionalnog programa za prilagođavanje zahtjevima globalizacije i prijelaza na ekonomiju utemeljenu na znanju (Šoljan, 2007). Kako bi se udovoljilo zahtjevima novih razvojnih trendova javlja se potreba za reformom obrazovanja (Baranović, 2006a). Međunarodna zajednica aktivno zagovara globalni reformski proces standardizacije znanja za suživot u globaliziranom svijetu, kao što su OECD-ov DeCeCo projekt, Europski okvir ključnih kompetencija za cjeloživotno obrazovanje Europske Unije, UN-ovi ciljevi održivog razvoja (Matanaović, 2017). Obrazovni standard predstavljaju precizno formulirani ciljevi obrazovanja u vidu ishoda učenja, a njihova ostvarenost provjerava se vanjskom evaluacijom, posebice međunarodnim ispitivanjima učeničkog znanja kao što su TIMMS ili PISA (Matanović, 2019). U središtu nove nastavne kulture je učenik (Bašić, 2007a). Ona podrazumijeva aktivno stjecanje kompetencija i primjenu znanja koja se usmjerava na rješavanje problema uz uvažavanje individualnih puteva učenja te teži većem udjelu samostalnog učenja (Wacker i sur, 2013). Uloga nastavnika je poticanje i praćenje procesa učenička tijekom učenja.

Hrvatski obrazovni sustav bio je pod utjecajem različitih obrazovnih tradicija vezanih uz promjene političkih sistema (Barać, 2019). Do Drugog svjetskog rata najizraženiji je bio utjecaj njemačke obrazovne tradicije, nakon toga sovjetske obrazovne tradicije, a nakon državnog osamostaljenja, SADa i Velike Britanije (Matanović, 2017). Prema Žiljak (2013) Hrvatska je do sada imala dvije faze promjene obrazovne politike. Prva faza je započela u ratnom razdoblju i donijela je promjene sadržaja vezanih uz 
nacionalni identitet, uvođenje vjerskog odgoja te ukidanje sadržaja povezanih s ideologijom i funkcioniranjem socijalističkog političkog sustava. Druga faza započela je paralelno s pregovorima za članstvo u Europskoj uniji pa Hrvatska donosi niz strateških dokumenata, zakonska rješenja i odluka vezanih uz obrazovanje u skladu sa strategijama Europske unije (europeizacija hrvatske obrazovne politike). Jedan od temeljnih razvojnih dokumenata iz te faze je Plan razvoja sustava odgoja $\mathrm{i}$ obrazovanja 2005. - 2010 kojeg je Vlada Republike Hrvatske usvojila 2005. godine, a koji se temelji na sveobuhvatnu promišljanju sustava odgoja i obrazovanja (MZOŠ, 2005). U 2007. godini izrađena je Strategija za izradbu i razvoj Nacionalnoga kurikuluma za predškolski odgoj, opće obvezno i srednjoškolsko obrazovanje (NOK, 2011). Navedene, a i brojne druge aktivnosti, kao što je ostvarivanje reformskoga projekta škola poznat pod nazivom Hrvatski nacionalni obrazovni standard (HNOS) 2006. godine, uvođenje Bolonjskog procesa 2001. godine, državne mature 2010. godine, osnivanje ključnih agencija za unapređenje obrazovanja (Žiljak, 2013), stvorile su važne pretpostavke za osmišljavanje i provođenje dubljih zahvata u odgojno-obrazovnomu sustavu na nacionalnoj razini, uključujući i izradbu Nacionalnoga okvirnoga kurikuluma (NOK, 2011).

Nacionalni okvirni kurikulum za predškolski odgoj i obrazovanje te opće obvezno i srednjoškolsko obrazovanje (2011) je temeljni dokument školstva koji određuje sastavnice predškolskoga, općega i srednjoškolskoga odgoja i obrazovanja te ujedno definira osnovne odgojno - obrazovne vrijednosti, ciljeve, načela i način samovrednovanja i vrednovanja učeničkih postignuća (Peharda, 2019). Temeljno obilježje Nacionalnoga okvirnoga kurikuluma je usmjerenost na učeničke kompetencije i učenička postignuća, odnosno ostvarenje predviđenih ishoda učenja koji će pripremiti učenike za cjeloživotno obrazovanje (NOK, 2011). Kako bi osigurala da poduzete mjere u obrazovanju budu u skladu $\mathrm{s}$ predviđenim strategijama Europske unije Hrvatska je 2014. donijela Strategiju obrazovanja, znanosti i tehnologije kojom je uspostavljen okvir za primjenu koncepta cjeloživotnog učenja u Hrvatskoj ali i ciljevi čije se postizanje očekuje do 2025. godine. Temeljem Strategije, provedba cjelovite kurikularne reforme započela je uvođenjem eksperimentalnog programa u pojedine osnovne i srednje škole u školskoj godini 2018./2019. Novim Zakonom o odgoju i obrazovanju u osnovnoj i srednjoj školi (NN 68/18), uspostavljen je okvir za donošenje 40 kurikuluma. Cjelovita kurikularna reforma započela je u svim osnovnim i srednjim školama u školskoj godini 2019./2020. (Barać 2019).

Kurikulum predmeta Priroda donesen je 2019. godine (NN 7/2019). Prema njemu svrha učenja nastavnoga predmeta Priroda je razumijevanje svijeta u kojemu živimo kako bi se u njemu održivo živjelo. Naglasak je na razumijevanju osnovnih koncepata prirodnih znanosti te na razumijevanju metoda koje se mogu primijeniti u svakodnevnome životu za stjecanje spoznaja i donošenje odgovornih odluka. Aktivnim uključivanjem učenika u proces učenja potiče se dublje razumijevanje pojava i procesa u prirodi te razvija osjetljivost i odgovornost prema okolini. Upoznavanjem svijeta oko sebe učenik stvara predodžbu o bogatstvu njegove različitosti, postupno spoznajući vlastito mjesto $\mathrm{i}$ ulogu u zajednici i svijetu (MZOŠ, 2019).

Kurikulum nastavnoga predmeta Priroda organiziran je prema Nacionalnom dokumentu prirodoslovnoga područja kurikuluma, u četiri makrokoncepta: Organiziranost prirode, Procesi $i$ međudjelovanja, Energija, te Prirodoznanstveni pristup. Makrokoncepti se međusobno prožimaju, objašnjavaju jedan drugoga integrirajući spoznaje i ideje temeljnih prirodnih znanosti. Kurikulum nastavnoga predmeta Priroda sadržajno se znatno promijenio u odnosu na Nastavni plan i program donesen 2006. godine gdje su učenici učili o staničnoj građi, građi životinjskog i biljnog organizma te uzgoju hrane i zaštiti životinja i biljaka (MZOŠ, 2006). Prema aktualnom kurikulumu učenici u petom 
razredu istražuju svijet koji ih okružuje provodeći mjerenja i opažanja, usvajajući metodologiju prirodoznanstvenoga istraživanja s njegovim osnovnim etapama i načelima. Promatranjem, pokusima i terenskim istraživanjima upoznaju koncept tvari i čestične građe prirode, istražuju svojstva tla, vode i zraka te razmatrajući životne uvjete, donose zaključke o odgovarajućim prilagodbama živih bića. Povezuju osobinu promjenjivosti živih bića s prilagodbama na različite životne uvjete te dovode u vezu promjene uvjeta u prošlosti Zemlje s promjenama životnih oblika i evolucijom života na Zemlji. Razlikuju osnovne izvore energije upoznajući pojam obnovljivih i neobnovljivih izvora (MZOŠ, 2019).

Kako je tlo do sada bilo vrlo malo zastupljeno u redovnoj nastavi petog razreda osnovne škole (Nastavna tema Uzgoj i zaštita životinja, MZOŠ, 2006) cilj ovog rada bio je ispitati zainteresiranost učenika petih razreda III. osnovne škole Varaždin za istraživanje sadržaje vezanih uz cjelinu Tlo.

\section{METODE}

Istraživanje je obuhvatilo 37 učenika dva peta razreda III. Osnovne škole Varaždin. Učenici su tijekom prvog polugodišta (od 9. do 12. mjeseca) ispunili pet anketnih upitnika putem online obrasca Google forms na satu Prirode pomoću mobilnih i tablet uređaja.

Na početku obrade nastavnih sadržaja vezanih uz cjelinu Tlo (9. mjesec) ispitana je motivacija učenika za učenje predmeta Priroda (upitnik 1). Upitnik je izrađen i prilagođen prema MSLQ upitniku (Duncan i McKeachie, 2015). Sastojao se od 27 tvrdnji koje su ispitivale intrinzičnu i ekstrinzičnu motivaciju, osobnu procjenu važnosti učenja prirode, lokus unutarnje kontrole, procjena vlastite uspješnosti i anksioznost pri provjeri znanja iz Prirode. Učenici su trebali izraziti stupanj slaganja s navedenim tvrdnjama koristeći se Likertovom skalom od 1 do 4 pri čemu su stupnjevi slaganja bili sljedeći: 1 uopće se ne slažem, 2 - ne slažem se, 3 - slažem se, 4 - potpuno se slažem.

Prije obrade nastavnih sadržaja vezanih uz cjelinu Tlo ispitano je predznanje učenika o toj temi. Pomoću tehnike učenja Oluja ideja učenici su na ploču ispisali sve pojmove koje su do sada čuli o zadanoj temi. Učenici su također individualno u radnim listićima odgovarali na tri pitanja:

1. Zašto je tlo važno?

2. Kako nastaje tlo?

3. Što možemo naći u tlu?

$\mathrm{Na}$ temelju provedene Oluje ideja izrađen je Upitnik 2. koji je ispitivao zainteresiranost učenika za istraživanje sadržaja vezanih uz cjelinu Tlo. Učenici su trebali izraziti stupanj zainteresiranosti za istraživanje i proučavanje dvadeset tema vezanih uz tlo na Likertovoj skali od 1 do 4 pri čemu su stupnjevi zainteresiranosti bili sljedeći: 1 - uopće me ne zanima, 2 - ne zanima me, 3 - zanima me, 4 vrlo sam zainteresiran.

Cjelina tlo razrađena je u 14 nastavnih sati (od čega 1 nastavni sat čini pisana provjera znanja, a 1 nastavni sat ponavljanje i prezentacija projekta) i 9 nastavnih tema (Građa tla, Vrste tla, Svojstva tla, Životni uvjeti u tlu, Mjerenje temperature tla, Projekt temperatura tla kroz godišnja doba, Izrada lumbrikarija, Prilagodba živih bića životnim uvjetima u tlu, Utjecaj živih bića na životne uvjete u tlu).

Obrada cjelina vezanih uz tlo temeljila se na terenskoj nastavi i pokusima kao što su propusnost tla, opipavanje tla, taloženje čestica tla u menzuri, izrada lumbrikarija uz grupno kolaborativno učenje koje je, za razliku od suradničkog učenja, omogućuje učenicima veću slobodu u radu i izvršavanju zadataka. Učenici su sami organizirali rad unutar grupe uz minimalno vodstvo učitelja. 
Tijekom obrade cjelina vezanih uz tlo Upitnikom 4. ispitano je razredno ozračje na satovima Prirode (10 mjesec). Upitnik je izrađen i prilagođen prema anketnom upitniku Razredno-nastavno ozračje (Jagić i Jurčić, 2006). Sastojao se od 23 tvrdnji koje su ispitivale: osjećaj straha od neuspjeha, učiteljevu podršku, koheziju razreda i zadovoljstvo nastavom. Učenici su trebali izraziti stupanj slaganja s navedenim tvrdnjama koristeći se Likertovom skalom od 1 do 4 pri čemu su stupnjevi slaganja bili sljedeći: 1 - uopće se ne slažem, 2 - ne slažem se, 3 - slažem se, 4 - potpuno se slažem. Učenici su također trebali navesti prijedloge za poboljšanje nastave Prirode.

U 11. mjesecu ispitano je stav o kolaboraciji tijekom nastave Prirode (upitnik 3). U upitniku se umjesto izraza kolaboracija koristi izraz zajedničko učenje. Upitnik je izrađen i prilagođen prema anketnom upitniku Kalayici i Humiston (2015) i sastojao se od 20 tvrdnji. Učenici su trebali izraziti stupanj slaganja s navedenim tvrdnjama koristeći se Likertovom skalom od 1 do 4 pri čemu su stupnjevi slaganja bili sljedeći: 1 - uopće se ne slažem, 2 - ne slažem se, 3 - slažem se, 4 - potpuno se slažem. Učenici su također trebali navesti vještine koje su stekli takvim načinom rada.

Prije pisane provjere znanja (12. mjesec) ispitane su strategije koje učenici primjenjuju tijekom učenja Prirode (upitnik 5). Upitnik se sastojao od 24 tvrdnje koje su ispitivale: proces učenja, način organizacije, kritičko mišljenje, unutarnju kontrolu, vrijeme i uvjete učenja, trud, suradnju s drugim učenicima tijekom učenja i traženje pomoći. Učenici su trebali izraziti stupanj slaganja s navedenim tvrdnjama koristeći se Likertovom skalom od 1 do 4 pri čemu su stupnjevi slaganja bili sljedeći: 1 uopće se ne slažem, 2 - ne slažem se, 3 - slažem se, 4 - potpuno se slažem. Učenici su također od nekoliko ponuđenih odgovora trebali zaokružiti ono što najčešće koriste prilikom učenja Prirode (knjigu, Internet, bilježnicu...).

\section{REZULTATI}

Rezultati ispitivanja (tablica 1) učeničke motivacije za učenje predmeta Priroda (upitnik 1) pokazali su visoku intrinzičnu motivaciju učenika. Svi ispitanici rekli su da se osjećaju uspješno kada razumiju Prirodu, a čak njih 87,8 \% reklo je da im je znanje iz Prirode bitnije od ocjene. lako im je znanje bitnije od ocjene također se pokazalo da im je i ocjena važna ( $97.5 \%$ učenika reklo je da im je važno imati odličnu ocjenu iz Prirode). Priroda im je zanimljiv predmet (95 \%) i smatraju da će im znanje iz Prirode koristiti u drugim predmetima (90.2 \%) te ulažu trud u učenje $(95.1 \%)$ i smatraju da se problemi u učenju javljaju ako se ne trude dovoljno (80.3 \%). Skoro svi ispitanici, njih $97.6 \%$ vjeruju da iz Prirode mogu dobiti ocjenu odličan. Unatoč tome što su izrazito motivirani za učenje Prirode, njih $56.6 \%$ osjeća neku vrstu nelagode tijekom rješavanja ispita iz Prirode.

\begin{tabular}{|c|c|c|c|c|}
\hline Pitanje/stupanj slaganja & $\begin{array}{l}\text { Uopće se ne } \\
\text { slažem }\end{array}$ & Ne slažem se & Slažem se & $\begin{array}{l}\text { Potpuno se } \\
\text { slažem }\end{array}$ \\
\hline \multicolumn{5}{|l|}{ Intrinzična motivacija } \\
\hline $\begin{array}{l}\text { 22.Znanje iz Prirode koje posjedujem važnije mi je od } \\
\text { ocjene koju ću dobiti. }\end{array}$ & $9.8 \%$ & $2.4 \%$ & $29.3 \%$ & $58.5 \%$ \\
\hline 4. Osjećam se uspješno kada razumijem Prirodu. & $0 \%$ & $0 \%$ & $9.8 \%$ & $90.2 \%$ \\
\hline \multicolumn{5}{|l|}{ Ekstrinzična motivacija } \\
\hline $\begin{array}{l}\text { 13. Znanje iz Prirode pomoći će mi u budućnosti za } \\
\text { dobivanje dobrog posla. }\end{array}$ & $2.4 \%$ & $9.8 \%$ & $43.9 \%$ & $43.9 \%$ \\
\hline $\begin{array}{l}\text { 16. Važno mi je imati odličnu ocjenu iz Prirode. } \\
\text { Osobna procjena važnosti učenja prirode }\end{array}$ & $0 \%$ & $2.4 \%$ & $19.5 \%$ & $78 \%$ \\
\hline 12. Znanje iz Prirode koristit će mi u drugim predmetima. & $2.4 \%$ & $7.3 \%$ & $14.6 \%$ & $75.6 \%$ \\
\hline 7. Predmet Priroda mi je zanimljiv. & $2.5 \%$ & $2.5 \%$ & $10 \%$ & $85 \%$ \\
\hline \multicolumn{5}{|l|}{ Lokus unutarnje kontrole } \\
\hline $\begin{array}{l}\text { 6. Ako imam problem u učenju Prirode, to je zato jer se } \\
\text { nisam dovoljno potrudio. }\end{array}$ & $0 \%$ & $9.8 \%$ & $24.4 \%$ & $65.9 \%$ \\
\hline 5. Ulažem trud u učenje Prirode. & $0 \%$ & $4.9 \%$ & $24.4 \%$ & $70.7 \%$ \\
\hline
\end{tabular}




\begin{tabular}{|c|c|c|c|c|}
\hline Pitanje/stupanj slaganja & $\begin{array}{l}\text { Uopće se ne } \\
\text { slažem }\end{array}$ & Ne slažem se & Slažem se & $\begin{array}{l}\text { Potpuno se } \\
\text { slažem }\end{array}$ \\
\hline \multicolumn{5}{|l|}{ Procjena vlastite uspješnosti } \\
\hline 21. Vjerujem da iz Prirode mogu dobiti ocjenu odličan. & $0 \%$ & $2.4 \%$ & $19.5 \%$ & $78 \%$ \\
\hline $\begin{array}{l}\text { 14. Uvjeren sam da mogu razumjeti i najteže dijelove } \\
\text { učenja iz Prirode. }\end{array}$ & $0 \%$ & $7.3 \%$ & $43.9 \%$ & $48.8 \%$ \\
\hline \multicolumn{5}{|l|}{ Anksioznost pri provjeri znanja iz prirode } \\
\hline 24. Osjećam nelagodu kada rješavam ispit iz Prirode. & $26.8 \%$ & $26.8 v$ & $22 \%$ & $24.4 \%$ \\
\hline 27. Srce mi ubrzano kuca kada rješavam ispit iz Prirode. & $24.4 \%$ & $22 \%$ & $24.4 \%$ & $29.3 \%$ \\
\hline
\end{tabular}

Rezultati ispitivanja učeničke zainteresiranost za istraživanje sadržaja vezanih uz cjelinu Tlo (upitnik 2) pokazali su da je između $88.9 \%$ - $97.3 \%$ učenika vrlo zainteresirano ili zainteresirano za istraživanje sadržaja vezanih uz cjelinu Tlo (neke od ponuđenih tema bile su: vrste tla, propusnost, rahlost, tvrdoća, životinje i biljke koje žive i raste u tlu, nevidljivi organizmi u tlu, fosili, utjecaj reljefa i klime na tlo, količina zraka i vode u tlu...) Sve teme pokazale su se jednako zanimljivim. Ni jedna tema nije se pokazala kao posebno zanimljivom ili nezanimljivom.

Rezultati ispitivanja (tablica 2) učeničkih stavova o grupnom kolaboracijskom radu (upitnik 3) pokazali su da učenici imaju pozitivan stav o zajedničkom učenju, da ih ono potiče na aktivno sudjelovanje u nastavi (96.6 \%) te da je atmosfera pri takvom načinu rada opuštenija (91.9 \%). Smatraju da se takav oblik rada treba češće provoditi (100 \%) i da ono ima pozitivan učinak na njihovo samopouzdanje (83.8 $\%)$ i rezultate $(97,3 \%)$.

\begin{tabular}{|c|c|c|c|c|}
\hline Pitanje/ stupanj slaganja & $\begin{array}{c}1 \\
\text { Uopće se ne } \\
\text { slažem }\end{array}$ & $\stackrel{2}{2}$ Ne Slažem se & $\begin{array}{c}3 \\
\text { Slažem se }\end{array}$ & $\begin{array}{c}4 \\
\text { Potpuno se slažem }\end{array}$ \\
\hline 1. Više naučim ako učim sam. & $13,9 \%$ & $25 \%$ & $33,3 \%$ & $27,8 \%$ \\
\hline $\begin{array}{l}\text { 3. Više volim rješavati zadatke sam nego kao dio } \\
\text { grupe. }\end{array}$ & $35,1 \%$ & $27 \%$ & $16,2 \%$ & $21,6 \%$ \\
\hline $\begin{array}{l}\text { 5. Zajednički rad potiče učenike da aktivno } \\
\text { sudjeluju u nastavi. }\end{array}$ & $0 \%$ & $5,4 \%$ & $29,7 \%$ & $64,9 \%$ \\
\hline $\begin{array}{l}\text { 6. Težak zadatak će se riješiti brže ako ga rješava } \\
\text { grupa učenika. }\end{array}$ & $0 \%$ & $0 \%$ & $10,8 \%$ & $89,2 \%$ \\
\hline $\begin{array}{l}\text { 10. Atmosfera na satu je opuštenija kada radimo } \\
\text { i učimo zajedno. }\end{array}$ & $0 \%$ & $8,1 \%$ & $24,3 \%$ & $67,6 \%$ \\
\hline 13. Zajedničkim učenjem jačamo samopouzdanja & $5,4 \%$, & $10,8 \%$, & $18,9 \%$, & $64,9 \%$ \\
\hline 17. Zajedničko učenje treba se češće provodit. & $0 \%$, & $0 \%$ & $29,7 \%$ & $70,3 \%$ \\
\hline $\begin{array}{l}\text { 18. Postižemo bolje rezultate kada radimo } \\
\text { zajedno nego kada radimo svaki za sebe. }\end{array}$ & $0 \%$ & $2,7 \%$ & $27 \%$ & $70,3 \%$ \\
\hline $\begin{array}{l}\text { 20. Zajedničkim učenjem stječemo vještine koje } \\
\text { inače ne bi stekli da učimo sami. }\end{array}$ & $0 \%$ & $8,1 \%$ & $27 \%$ & $64,9 \%$ \\
\hline
\end{tabular}

Rezultati ispitivanja (tablica 3) razrednog ozračja (upitnik 4) pokazali su da polovica učenika osjeća strah i nelagodu zbog potencijalnog neuspjeha na nastavi Prirode iako imaju osjećaj da ih učitelj na nastavi potiče i hrabri (93.7 \%) i podjednako cijeni svakog učenika (65.6 \%). Malo više od polovice učenika smatra da ne postoji zavist u razredu ( $56.3 \%)$, ali isto tako da nisu svi za zajedničke aktivnosti na nastavi (75\%). Unatoč tome, smatraju kada je potrebno da je razred jedinstven (64.5\%). Zadovoljni su s nastavom Prirode i malo više od polovice učenika ne bi mijenjali način rada (54.8\%). Od onih učenika koji bi mijenjali način rada većina njih je navela da bi htjela na nastavi Prirode biti češće vani.

Tvrdnja „Kad sudjelujem u radu, govorim ili odgovaram na pitanja na satu Prirode, ukoliko me učitelj ocjenjuje, govorim s mnogo straha." se pokazala zbunjujuća za neke učenike pa je treba preoblikovati u tvrdnju: „Ukoliko učitelj Prirode na satu ocjenjuje moj rad, osjećam strah.“. 
Također učenici su imali problema s razumijevanjem riječi jedinstven u tvrdnji: „Kad je potrebno naš razred je jedinstven." pa je treba preoblikovti u tvrdnju: „Kad je potrebno naš razred je složan.“

Tablica 3 Prikaz rezultata ispitivanja razrednog ozračja

\begin{tabular}{|c|c|c|c|c|}
\hline Pitanje/skala & $\begin{array}{l}1 \\
\text { Uopće se ne } \\
\text { slažem }\end{array}$ & $\stackrel{2}{2}$ & $\begin{array}{c}3 \\
\text { Slažem se }\end{array}$ & $\begin{array}{l}4 \\
\text { Potpuno se } \\
\text { slažem }\end{array}$ \\
\hline \multicolumn{5}{|l|}{ Osjećaj straha od neuspjeha } \\
\hline $\begin{array}{l}\text { 1.Kad čujem svoje ime za vrijeme nastave odmah me } \\
\text { obuzme nelagoda }\end{array}$ & $25 \%$ & $25 \%$ & $28,1 \%$ & $21,9 \%$ \\
\hline $\begin{array}{l}\text { 2.Kad sudjelujem u radu, govorim ili odgovaram na pitanja } \\
\text { na satu Prirode, ukoliko me učitelj ocjenjuje, govorim s } \\
\text { mnogo straha. }\end{array}$ & $21,9 \%$ & $28,1 \%$ & $25 \%$ & $25 \%$ \\
\hline \multicolumn{5}{|l|}{ Učiteljeva podrška } \\
\hline 10.Učitelj prirode cijeni samo napredne učenike & $28,1 \%$ & $37,5 \%$ & $12,5 \%$ & $21,9 \%$ \\
\hline 7. Učitelj prirode me hrabri i potiče u radu & $6,3 \%$ & $0 \%$ & $28,1 \%$ & $65,6 \%$ \\
\hline \multicolumn{5}{|l|}{ Kohezija razreda } \\
\hline $\begin{array}{l}\text { 11. Kad neki učenik dobiva bolje ocjene, svi ostali su mu } \\
\text { zavidni }\end{array}$ & $18,8 \%$ & $37,5 \%$ & $28,1 \%$ & $15,6 \%$ \\
\hline $\begin{array}{c}\text { 14.Smatram da neki prijatelji iz razreda nisu osobito za } \\
\text { zajedničke aktivnosti na nastavi }\end{array}$ & $12,5 \%$ & $12,5 \%$ & $37,5 \%$ & $37,5 \%$ \\
\hline 17.Kad je potrebno naš razred je jedinstven & $9,7 \%$ & $25,8 \%$ & $29 \%$ & $35,5 \%$ \\
\hline \multicolumn{5}{|l|}{ Zadovoljstvo nastavom } \\
\hline 19. Smatram da je na nastavi prirode dosadno & $71 \%$ & $3,2 \%$ & $3,2 \%$ & $22,6 \%$ \\
\hline $\begin{array}{l}\text { 23. Kada bih bio/la u mogućnosti promijenila bi način rada } \\
\text { u nastavi Prirode }\end{array}$ & $38,7 \%$ & $16,1 \%$ & $22,6 \%$ & $22,6 \%$ \\
\hline
\end{tabular}

Rezultati ispitivanja (tablica 4) primjene strategija učenja (upitnik 5) pokazuju da učenici smatraju znanje iz Prirode korisnim u različitim projektima i praktičnim radovima $(82,6 \%)$ te da gradivo Prirode povezuju s drugim predmetima (80,8 \%). Prirodu uče redovito (100 \%), na mjestu gdje se mogu koncentrirati (98.1\%). Većina (73.1\%) tijekom procesa učenja Prirode izrađuje sheme, tablice, crteže ili grafove $(55.8 \%)$ i postavljaju si pitanja kako bi provjerili jesu li dobro naučili (88.4 \%). Trude se biti uspješni bez obzira sviđa li im se gradivo ili ne (96.2 \%), više od polovice učenika uči zajedno s drugim učenicima iz razreda (60.8 \%), a njih 70 \% traži pomoć drugih učenika ako im nešto nije jasno. Skoro svi učenici $(96.2 \%)$ su rekli da su ih satovi Prirode potaknuli da stvore svoje mišljenje o onome o čemu uče.

Tvrdnju 5.: „Kada učim Prirodu crtam grafove uz ono što trebam naučiti." treba preoblikovti u: „Kada učim Prirodu crtam ono što trebam naučiti." jer neki učenici nisu znali objasniti značenje riječi graf. Također učenici su imali problema s razumijevanjem riječi koncetrirati u tvrdnji 13. (Obično učim na mjestu gdje se mogu koncentrirati.) i instrukcije u tvrdnji 22. (Idem na instrukcije iz Prirode.) pa te tvrdnje treba preoblikovati u: „Obično učim na mjestu gdje mogu imati mir." $i$ „Potrebna mi je pomoć u učenju kod kuće ili dodatni satovi iz Prirode.".

Tablica 4 Prikaz rezultata ispitivanja primjene strategija učenja

Pitanje/skala

Proces učenja

1.Pokušavam povezati gradivo Prirode s drugim predmetima.

2.Znanje iz Prirode puno primjenjujem u aktivnostima kao što su projekti, rasprave i praktični radovi koje radimo na satu. Organizacija

5.Kada učim Prirodu crtam grafove uz ono što trebam naučiti. 3.Kada učim Prirodu radim sheme, mape, crteže i tablice uz ono što trebam naučiti.

Kritičko mišljenje

7.Na satovima Prirode raspravljamo o zaključcima i uvažavamo drukčije ideje.

6.Satovi Prirode me potiču da stvorim svoje mišljenje o onom o čemu učimo.

$\begin{array}{cccc}\begin{array}{c}1 \\ \text { Uopće se ne } \\ \text { slažem }\end{array} & \begin{array}{c}\mathbf{2} \\ \text { Ne Slažem se }\end{array} & \begin{array}{c}\mathbf{3} \\ \text { Slažem se }\end{array} & \begin{array}{c}\mathbf{4} \\ \text { Potpuno se } \\ \text { slažem }\end{array} \\ 3,8 \% & 15,4 \% & 32,7 \% & 48,1 \% \\ 1,9 \% & 15,4 \% & 28,8 \% & 53,8 \% \\ & & & \\ 21,2 v & 23,1 \% & 21,2 \% & 34,6 \% \\ 9,6 \% & 17,3 \% & 32,7 \% & 40,4 \% \\ & & & \\ & 5,8 \% & 30,8 \% & 63,5 \% \\ 1,9 \% & 1,9 \% & 23,1 & 73,1 \\ & & & \end{array}$


Pitanje/skala

Unutarnja kontrola

10.Kada učim za pisanu provjeru iz Prirode često si postavljam pitanja da bih bio siguran jesam li dobro naučio.

12.Kad učim Prirodu uvijek pokušavam otkriti glavnu ideju ili misao.

Vrijeme i uvjeti učenja

13.Obično učim na mjestu gdje se mogu koncentrirati. 14.Redovito učim i rješavam zadaće iz Prirode. Trud

16.Trudim se biti uspješan na Prirodi čak i ako mi se ne sviđa to što učimo.

17.Učim samo ono što je lagano. Kolaboracija

21.Često Prirodu učim zajedno s učenicima iz razreda. 20.Zajednički rješavamo domaće zadaće iz Prirode. Traženje pomoći

23. Kada ne razumijem nešto iz Prirode tražim da mi to drugi učenici objasne.

22.Idem na instrukcije iz Prirode
1

Uopće se ne slažem

2

2

3

Slažem se

4

$1,9 \%$

$9,6 \%$

$19,2 \%$

slažem

$69,2 \%$

$9,6 \%$

$36,5 \%$

$53,8 \%$

$1,9 \%$

$13,5 \%$

$15,4 \%$

$84,6 \%$

$84,6 \%$

3,8

$3,8 \% \quad 17,3 \%$

$78,8 \%$

$46,2 \%$

$13,5 \%$

$9,6 \%$

$30,8 \%$

$13,7 \%$

$25,5 \%$

$21,6 \%$

$39,2 \%$

$19,6 \%$

$21,6 \mathrm{v}$

$17,6 \%$

$41,2 \%$

$14 \%$

$16 \%$

$26 \%$

$44 \%$

$60,8 \%$

$5,9 v$

$5,9 \%$

$27,5 \%$

Tijekom primjene tehnike Oluja ideja, čiji cilj je bio ispitati predznanje učenika o zadanoj temi, učenici su spomenuli svojstva tla (plodnost, rahlost, propusnost, vlaga, tvrdoća, veličina zrnaca, miris, vlažnost, ljepljivost, boja, gustoća), vrste tla (ilovača, crvenica, crnica, humus, glina...), život pod zemljom, fosile, tunele u tlu, bakterije, jajašca životinja, naftu, arheološka nalazišta, rijeke ponornice, ljekovitost tla...

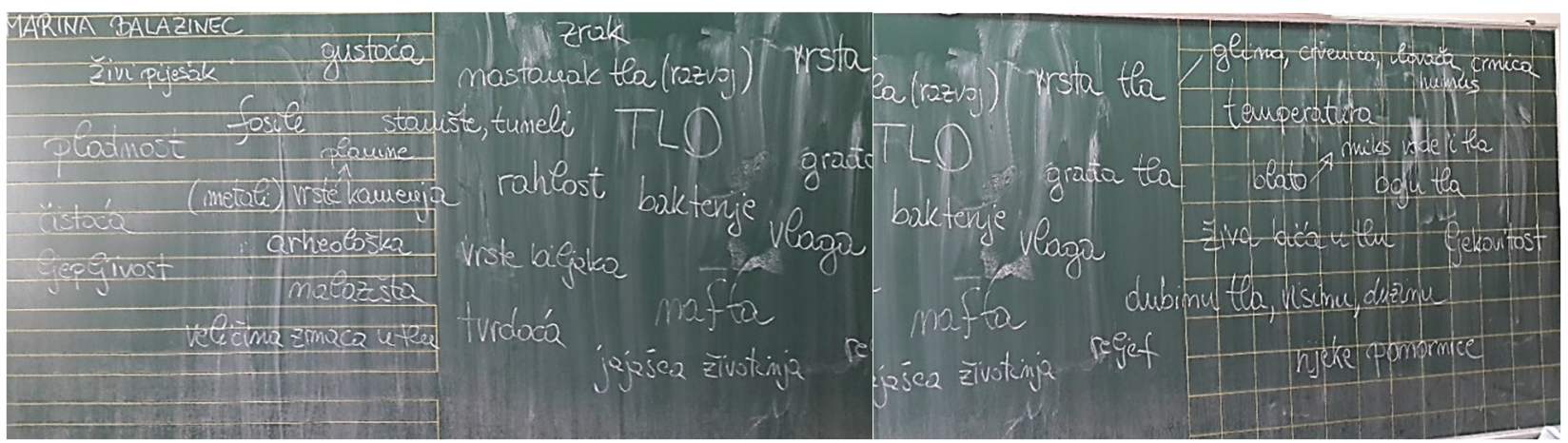

Slika 1 Oluja ideja na temu istraživanje Tla

Na pitanje Zašto je tlo važno? učenici su većinom odgovarali:

važnost tla za uzgoj biljaka: tlo je važno za rast biljaka, rast drveća koje nam daje kisik, za uzgoj raznovrsnih biljaka, za uzgoj voća i povrća bez njega ne bi imali hranu.

važnost tla kao podloge za gradnju i život: za hodanje, tlo je važno jer na njemu je cijeli svijet, to je kuća životinja, da živimo na njemu i gradimo kuće.

Na pitanje Kako nastaje tlo? učenici su većinom odgovarali:

rušenje planina: tako da ljudi ruše planine i sruše zemlju, od kamenja, pijeska i zemlje, tako da se planine rušiju.

uginule biljke i životinje: od mrtvih životinja, od mrtvih životinja i biljaka, uginulih životinja $i$ njihovog izmeta.

Bilo je i nekih pojedinačnih odgovora kao što su: od vlage, grančica, bakterija i zraka, od ugljena.

Na pitanje Što možemo naći u tlu? učenici su većinom odgovarali: kamenje, vodu, biljke, životinje (kukce, mrave, gliste, krtove) zemlju, korijenje travu, metal (zlato i srebro), toplinu, kosti. Bilo je i nekih pojedinačnih odgovora kao što su: sjemenke, smeće, pijesak, naftu bakterije kosti, fosile, zrak, dijamante. 
Učenici su tijekom obrade nastavnih sadržaja vezanih uz cjelinu Tlo pokazali veliko zanimanje, pogotovo za terensku nastavu i pokuse.

\section{RASPRAVA}

Rezultati su pokazali da učenici u startu imaju vrlo visoku motivaciju za učenje Prirode i da im je to zanimljiv predmet iz kojeg se trude postići što bolji rezultat što je u skladu s rezultatima drugih istraživanja koja su provedena za tu dobnu skupinu (Ormerod, 1973; Braud i Driver, 2005; Sarwar i sur, 2011). Zainteresirani su i za istraživanje svih sadržaja povezanih s cjelinom Tlo. Da su učenici zainteresirani za proučavanje tla dokazuju i istraživanja koja se bave utjecajem vrtlarstva na uspjeh učenika (Klemmer, 2002; DeMarco i sur, 1999; Smith i sur, 2005) i koja pokazuju da vrtlarstvo ima pozitivan utjecaj na rezultate učenika i usvajanje sadržaja vezanih uz tlo i vrtlarenje.

Istraživanje je pokazalo da su učenici zadovoljni nastavom Prirode koja je bazirana na pokusima, istraživanju i kolaboracijskom grupnom radu. Vole zajednički učiti i raditi na rješavanju problema $i$ smatraju da tako brže dolaze do rješenja te da bi se takav način rada trebao provoditi češće što su pokazale i druge studije (Cohen, 1994; Wentzel, 1997; Hickey, 1997; Yackel i sur, 1991). Bryan i sur. (2011) su u svojoj studiji otkrili da kolaborativan način rada utječe i na motivaciju učenika dobne skupine između 14-16 godina.

Ono što bi učenici mijenjali na satovima Prirode je broj sati proveden vani, što ne čudi jer mnoga istraživanja ukazuju da učenici vole provoditi vrijeme izvan učionice i učiti vani (Borsos i sur. 2017; Borić i Škugor, 2014; Borsos i sur, 2018; Uitto i sur, 2016). Oluja ideja je pokazala da učenici imaju razne asocijacije vezane uz tlo i da ne percipiraju tlo samo kao nešto prljavo i statično mjesto u kojem se ništa ne događa kao što je to navedeno u istraživanju Ero-Tolliver i sur. 2013. Možda razlika u rezultatim proistječe iz različite dobne skupine ispitanika. Naime Ero-Tolliver i suradnici su istraživanje provodili na dobnoj skupini između 6 i 7 godina, dok su u ovom istraživanju učenici bili starosti između 10 i 11 godina. Rezultati su pokazali da učenici vide važnost tla većinom kao podloge za gradnju i rast biljaka i da nemaju jasnu sliku kako tlo nastaje, što je važno polazište za pripremu nastave uz temu Tlo za učenike Prirode.

\section{ZAKLUČAK I METODIČKI ZNAČAJ}

Rezultati pokazuju kako je kurikulum Prirode primjeren učenicima petih razreda jer im omogućuje boravak u prirodi $i$ istraživanje neposrednog okoliša (vode, tla i zraka) što je njima vrlo zanimljivo. Pokazatelji razmišljanja učenika uočeni u ovom radu značajni su učiteljima kako bi mogli usmjeriti svoje poučavanje ka dobivanju šire slike tla, kao sastavnice biosfere koja utječe na naše živote određujući koliko ćemo hrane proizvoditi, regulirajući klimu, kvalitetu vode i zraka, razgradnju i kruženje tvari.

Rezultati su dobiveni na malom broju ispitanika i ne mogu se generalizirati. Uzevši u obzir ovo ograničenje bilo bi dobro provesti istraživanje na većem uzorku učenika iz cijele Hrvatske, kako bi rezultati bili reprezentativni kao i vidjeti postoji li spolna razlika u motivaciji za učenje Prirode i sadržaja vezanih uz Tlo, te povezanost između kolaborativnog učenja i pozitivnog razrednog ozračja.

\section{LITERATURA}

Barać, I. (2019). Kurikularna reforma kao mjera političke ekonomije: diplomski rad. Fakultet političkih znanosti Sveučilišta u Zagrebu

Baranović, B. (2006a). Društvo znanja i nacionalni kurikulum za obavezno obrazovanje. U B. Baranović (ur.), Nacionalni kurikulum za obvezno obrazovanje u Hrvatskoj: različite perspektive. Zagreb: Institut za društvena istraživanja, str. 15-43. 
Bašić, S. (2007a). Nacionalni obrazovni standard - instrument kontroliranja učinkovitosti obrazovnog sustava, unapređivanja kvalitete nastave ili standardiziranja razvoja osobnosti? Pedagogijska istraživanja, 1,25.

Borić, E., Škugor, A. (2014). Achieving students' competencies through research-based outdoor science teaching. Croatian Journal of Education,16(1), 149-164.

Borsos, E., Borić, E., Patocskai, M. (2018). Be in: Teach Outdoors! Croatian Journal of Education, 20(3), 843-866.

Braund, M., Driver, M. (2005). Pupils' Attitudes to Practical Science around the KS2/3 Transition. Education, 3-13, 33(2), 2026.

Bryan, R. R., Glynn, S. M., Kittleson, J. M. (2011). Motivation, achievement, and advanced placement intent of high school students learning science. Science education, 95(6), 1049-1065.

Cohen, E. G. (1994). Restructuring the classroom: Conditions for productive small groups. Review of Educational Research, 64(1), 1-35.

DeMarco, L. W., Relf, D., McDaniel, A. (1999). Integrating gardening into the elementary school curriculum. HortTechnology, 9(2), 276-281.

Ero-Tolliver, I., Lucas, D., Schauble, L. (2013). Young children's thinking about decomposition: Early modeling entrees to complex ideas in science. Research in Science Education, 43(5), 2137-2152.

Hickey, D. T. (1997). Motivation and contemporary socio-constructivist instructional perspectives. Educational Psychologist, $32(3), 175-193$.

Matanović, I. (2017). Kurikularna reforma kao oblik standardizacije obrazovanja- pedagoško - didaktička refleksija. Život i škola: časopis za teoriju i praksu odgoja i obrazovanja, 63(1), 13-27.

MZOŠ (2005). Plan razvoja sustava odgoja i obrazovanja 2005. - 2010. Zagreb: Ministarstvo znanosti, obrazovanja i športa Republike Hrvatske.

MZOŠ (2006). Nastavni plan i program za osnovnu školu. Zagreb: Ministarstvo znanosti, obrazovanja i športa Republike Hrvatske.

MZOŠ (2011). Nacionalni okvirni kurikulum za predškolski odgoj i obrazovanje te opće obvezno i srednjoškolsko obrazovanje. Zagreb: Ministarstvo znanosti, obrazovanja i športa Republike Hrvatske.

MZO (2019). Kurikulum nastavnog predmeta Priroda za osnovne škole. Zagreb: Ministarstvo znanosti i obrazovanja Republike Hrvatske

Ormerod, M. B. (1973). Social and Subject Factors in Attitudes to Science. School science review, 54(189), 645-660.

Peharda, P. (2019). Usporedba ishoda učenja u udženicima i radnim bilježnicama iz Prirode i društva: diplomski rad, Fakultet za odgojne i obrazovne znanosti Sveučilište Jurja Dobrile u Puli

Sarwar, M., Naz, A., Noreen, G. (2011). Attitudes toward science among school students of different nations: A review study. Journal of College Teaching and Learning (TLC), 8(2).

Smith, L. L., Motsenbocker, C. E. (2005). Impact of hands-on science through school gardening in Louisiana public elementary schools. HortTechnology, 15(3), 439-443.

Šoljan N.N. (2007). Taksonomija svjetskih razvoja u obrazovanju prema de(kontrukciji pedagogije. U: V. Previšić, N.N Šoljan, N. Hrvatić (ur.) Pedagogija- prema cjeloživotnom obrazovanju i društveno znanje. Zagreb: HPD, 411-440.

Uitto, A., Juuti, K., Lavonen, J., Meisalo, V. (2006). Students' interest in biology and their out-of-school experiences. Journal of Biology Education, 40(3), 124-129.

Žiljak, T. (2013). Dvije faze obrazovne politike u Hrvatskoj nakon 1990. godine. Andragoški glasnik: Glasilo Hrvatskog andragoškog društva, 17(30), 7-23.

Wacker, A., Rohlfs, C. i Kramer, J. (2013). Sind Bildungsstandards Innovationsimpulse für Unterricht und Leistungsbeurteilung? Ein Querschnittvergleich der Einschätzungen von Lehrerinnen und Lehrern zu zwei Messzeitpunkten. Zeitschrift für Bildungsforschung, 3(2), 119-136. 


\title{
Interest of ten year olds for soil investigation
}

\author{
Marina Balažinec \\ $3^{\text {rd }}$ primary school Varazdin, Trg Ivana Perkovca 35, Varazdin \\ marina.barisic13@gmail.com I
}

\begin{abstract}
The National curriculum adopted in 2019. emphasizes understanding of basic science concepts and learning about environment where the student is able to make responsible decisions and live sustainably. It has changed significantly in content and according to it, students explore the world around them by taking measurements and observations. One of the study units is Investigation of soil. As the soil has so far been very little represented in the regular teaching of the fifth grade of primary school, the aim of this paper was to examine the interest of 37 students of the fifth grade III. elementary schools in Varazdin in soil study. During the first semester (9th to 12th months), students completed five survey questionnaires using the online Google Forms using mobile and tablet devices. The results have shown high motivation for learning Nature as well as for investigating soil, they want to have excellent results in Nature and success is very important to them. They also showed that they have some background in soil, but it is not clear to them it's genesis and the importance of soil is mentioned only as a basis for growth and construction. They have expressed a positive attitude towards collaborative group work and would like to spend more time outside. The survey should be conducted on a larger sample of respondents and explore the relationship between collaborative group work, the atmosphere and strategies used in learning, and motivation to learn Nature, interest in exploring soil, and strategies used during learning.
\end{abstract}

Keywords: soil investigation; survey questionnaires; collaborative learning; motivation; class atmosphere 